\title{
Optimasi Konsentrasi Kinetin dan Benzyl Amino Purine Pada Kultur Tunas Vanili (Vanilla planifolia)
}

\section{Optimization of Kinetin and Benzyl Amino Purine Concentrations in the Culture of Vanilla Shoots (Vanilla planifolia)}

\author{
Dyah Nuning Erawati $^{* 1}$, Yusriatul Mawaddah ${ }^{* 2}$, Siti Humaida ${ }^{* 3}$ dan Irma Wardati ${ }^{* 4}$ \\ *Jurusan Produksi Pertanian Politeknik Negeri Jember PO.BOX 164 Jember, 68101 Indonesia \\ ${ }^{1}$ dyah_nuning_eepolije.ac.id
}

\begin{abstract}
Vanilla has a potential to be developed through tissue culture techniques to anticipate the limitations of the parent plant as a source of planting material. The in vitro propagation ability of vanilla shoots needs to be controlled with the regulation of Kinetin and Benzyl Amino Purines. The interests of this study are 1) analysis of the response of vanilla explants at several Kinetin concentrations; 2) analysis of the response of vanilla explants at several concentrations of BAP and 3) analysis of the interaction of Kinetin and BAP on the response of vanilla explants to form shoot multiplication. The research was conducted at the Tissue Culture Laboratory Politeknik Negeri Jember from June to December 2020 using a factorial Completely Randomized Design (CRD). Factor 1 was the Kinetin concentration of 0.0, 1.0, $2.0 \mathrm{mg} . \mathrm{L}-1$ and the second factor was the concentration of BAP 0.5, 1.5, $2.5 \mathrm{mg}$.L-1. The results proved that the fastest shoot multiplication occurred on MS medium + Kinetin 2 mg.L-1 with a mean of 8.7 days after inoculation. The mean number of shoots was 7.6 shoots/explant with the highest average wet weight of 0.9 grams/explant at the addition of BAP $1.5 \mathrm{mg}$. L-1 at measurement 70 days after inoculation.
\end{abstract}

Keywords- kultur, multiplikasi, tunas, vanili,

\section{Pendahuluan}

Vanili (Vanilla planifolia) adalah tanaman penghasil bubuk vanili yang biasa dijadikan pengharum makanan karena memiliki kekayaan aroma yang tidak dapat digantikan oleh vanili sintetik [1], [2]. Perbanyakan tanaman vanili banyak dikembangkan melalui teknik kultur jaringan untuk mengantisipasi serangan penyakit layu Fusarium dan keterbatasan bahan tanam dari sulur tanaman induk [3], [4].

Kemajuan bioteknologi vanili berperan besar dalam konservasi plasma nutfah, rekayasa genetika, multiplikasi klonal dan produksi tanaman bebas penyakit. Optimalisasi dalam kultur aseptik, regenerasi tunas ganda, perakaran dan aklimatisasi planlet perlu dikembangkan untuk memperoleh protokol in vitro yang lebih efisien [5], [6].

Penggandaan tunas vanili melalui teknik mikropropagasi menggunakan media MurshigeSkoog menghasilkan kelompok tunas dengan penambahan 9,55 $\mu \mathrm{M}$ benzyladenin dan $100 \mathrm{ml} / \mathrm{liter}$ air kelapa [7]. Pertumbuhan tunas tiap eksplan vanili secara maksimal sebanyak 9 tunas/eksplan diperoleh dengan penambahan zat pengatur tumbuh BAP dan Kinetin pada komposisi 2:1 ppm [8]. Hal berbeda dilaporkan oleh [9] yang menyatakan bahwa penggandaan tunas vanili melalui teknik mikropropagasi hanya dipengaruhi oleh BAP (Benzyl Amino Purine) pada konsentrasi $3 \mathrm{mg} / \mathrm{liter}$ dengan rerata 3-4 tunas/eksplan pada 28 hari setelah inokulasi. 
Optimasi konsentrasi Kinetin dan BAP untuk penggandaan tunas kultur vanili perlu dilakukan. Oleh karena itu penelitian ini bertujuan untuk menganalisis respon eksplan vanili dengan stimulasi Kinetin atau BAP secara tunggal serta menganalisis interaksi Kinetin dan BAP terhadap respon eksplan vanili melalui teknik mikropropagasi.

\section{Metodologi Peneitian}

Penelitian dilakukan di Laboratorium Kultur Jaringan Politeknik Negeri Jember pada bulan Juni sampai bulan Desember 2020.

\section{A. Alat dan Bahan}

Alat yang akan digunakan adalah peralatan gelas (botol kultur, gelas ukur, petri dish, erlenmeyer, beaker glass); LAF (Laminar Air Flow), dissecting set, hot plate \& magnetic stirrer, pipet, autoklaf, neraca analitik, bunsen, gunting, kamera, lemari es dan alat tulis. Bahan yang dibutuhkan adalah bibit vanili, larutan stok media MS, Kinetin, BAP, gula, natrium hipoklorit, agar-agar, formalin, alkohol $70 \%$ dan $96 \%$, akuadest steril, spiritus, plastik wrapping, bakterisida, fungisida, larutan tween, kertas label.

\section{B. Rancangan Penelitian}

Penelitian didasarkan pada Rancangan Acak Lengkap (RAL) faktorial. Perlakuan penambahan level konsentrasi Kinetin dan BAP dalam medium Murashige-Skoog (MS) dengan 100 mg.L-1 inositol, 30 g.L-1 sukrosa, pH 5,8 dan 8 g.L-1 agaragar. Faktor 1 adalah konsentrasi Kinetin $0.0 \mathrm{mg}$.L1; 1.0 mg.L-1; 2.0 mg.L-1. Faktor 2 adalah konsentrasi BAP 0.5 mg.L-1; 1.5 mg.L-1; 2,5 mg.L-1. Data dianalisis dengan analisis Sidik Ragam dengan uji lanjut BNT (Beda Nyata Terkecil) $5 \%$.

\section{Hasil Dan Pembahasan}

\section{A. Waktu Kemunculan Tunas (hari)}

Pembentukan tunas dilihat pada ruas eskplan vanili yang mulai memunculkan tunas berwarna hijau muda. Penambahan Kinetin secara tunggal mempengaruhi waktu kemunculan tunas.

TABEL 1. RERATA WAKTU KEMUNCULAN TUNAS PADA BEBERAPA KONSENTRASI KINETIN

\begin{tabular}{lcl}
\hline Konsentrasi Kinetin & Saat Kemunculan Tunas \\
\hline 0 mg.L-1 & 10.8 & b \\
1 mg.L-1 & 10.4 & b \\
2 mg.L-1 & 8.7 & a
\end{tabular}

Keterangan: Angka-angka yang diikuti oleh huruf yang sama dinyatakan berbeda tidak nyata berdasar uji BNT 0,05 .

Berdasar Tabel 1 diketahui rerata waktu kemunculan tunas eksplan vanili yang tercepat 8.7 hari setelah inokulasi pada media MS dengan penambahan Kinetin $2 \mathrm{mg} / \mathrm{liter}$. Penambahan konsentrasi Kinetin $1 \mathrm{mg} /$ liter mempengaruhi kemampuan eksplan vanili memunculkan tunas pada 10.4 hari yang berbeda tidak nyata dengan perlakuan tanpa penambahan Kinetin.

Sesuai dengan hasil penelitian [10] bahwa penambahan 0,75 ppm Kinetin secara efisien dapat menyebabkan hilangnya dominasi apikal yang mungkin menghalangi pertumbuhan ketiak dan tunas adventif dalam kultur jaringan vanilla. [11] menyatakan bahwa Kinetin termasuk ke dalam kelompok sitokinin yang berfungsi untuk pengaturan pembelahan sel, membantu pertumbuhan jaringan. Kinetin dapat mendiferensiasi sel-sel ke arah pembentukan kemunculan tunas.

\section{B. Jumlah Tunas (pucuk)}

Jumlah tunas yang terbentuk pada eksplan vanili merupakan indikasi keberhasilan eksplan vanili menggandakan tunas akibat penambahan zat pengatur tumbuh dari golongan sitokinin.

TABEL 2. RERATA JUMLAH TUNAS PADA EKSPLAN VANILI DENGAN PENAMBAHAN KINETIN DAN BAP

\begin{tabular}{cccc}
\multicolumn{2}{c}{ Konsentrasi (mg.L-1) } & \multicolumn{2}{c}{ Rerata Jumlah Tunas } \\
Kinetin & BAP & & \\
\hline 0.0 & 0.5 & 3.39 & $\mathrm{ab}$ \\
0.0 & 1.5 & 7.56 & $\mathrm{~d}$ \\
0.0 & 2.5 & 8.61 & $\mathrm{~d}$ \\
1.0 & 0.5 & 5.33 & $\mathrm{bc}$ \\
1.0 & 1.5 & 3.78 & $\mathrm{abc}$ \\
1.0 & 2.5 & 5.56 & $\mathrm{c}$ \\
2.0 & 0.5 & 3.28 & $\mathrm{a}$ \\
2.0 & 1.5 & 5.33 & $\mathrm{bc}$ \\
2.0 & 2.5 & 5.22 & $\mathrm{abc}$ \\
\hline
\end{tabular}

Keterangan: Angka-angka yang diikuti oleh huruf yang sama dinyatakan berbeda tidak nyata berdasar uji BNT 0,05.

Tabel 2 memperlihatkan jumlah tunas terbanyak pada eksplan vanili yang ditanam dalam media MS + Kinetin 0.0 mg.L-1 + BAP 2.5 mg.L-1 dengan rerata 8.6 pucuk/eksplan yang berbeda tidak nyata dengan penambahan Kinetin 0.0 mg.L-1 + BAP 1.5 mg.L-1 saat eksplan berumur 70 hari setelah inokulasi. Penambahan sitokinin kedalam media tanam terbukti meningkatkan kemampuan eksplan vanili dalam penggandaan tunas.

Hal tersebut didukung oleh hasil penelitian [8], yaitu 2,0 mg/l BAP dan Kinetin $(20 \mu \mathrm{g} / \mathrm{g}$.f.wt $)$ lebih efektif menginduksi jumlah pucuk per eksplan tertinggi (7,6 pucuk) dengan rata-rata panjang $4,3 \mathrm{~cm}$. BAP merupakan salah satu jenis sitokinin yang efektif untuk induksi regenerasi pucuk dalam kultur jaringan tanaman. Studi saat ini menunjukkan bahwa BAP lebih efektif daripada Kinetin dalam meningkatkan perbanyakan tunas eksplan vanili. Lebih lanjut [12] menyatakan bahwa stimulasi BAP secara tunggal mempengaruhi multiplikasi tunas vanili dengan rerata jumlah tunas terbanyak 6.8 
Dyah Nuning Erawati, Yusriatul Mawaddah, Siti Humaida, Irma Wardati. Optimasi Konsentrasi Kinetin dan Benzyl Amino Purine Pada Kultur Tunas Vanili (Vanilla planifolia)

tunas/eksplan pada konsentrasi BAP $1 \mathrm{mg} . \mathrm{L}-1$ saat eksplan berumur 56 hari setelah inokulasi.

\section{Tinggi Tunas $(\mathrm{cm})$}

Tinggi tunas merupakan salah satu ciri dari pertumbuhan eksplan vanili yang merupakan indikator pertumbuhan tanaman sebagai pengukur terhadap pengaruh lingkungan dan perlakuan yang diberikan.

Penambahan Kinetin dan BAP kedalam media dasar MS berpengaruh tidak nyata terhadap tinggi tunas vanili. Berdasar Gambar 1 terlihat bahwa tunas tertinggi pada penambahan Kinetin 2 mg.L-1 + BAP 0,5 mg.L-1 dengan rerata tinggi $2,43 \mathrm{~cm}$. Tinggi tunas terendah pada penambahan Kinetin 0 mg.L-1 + BAP 2,5 mg.L-1 yaitu $1,17 \mathrm{~cm}$. Hal ini berkaitan dengan jumlah pucuk tunas yang terbentuk pada eksplan vanili. Apabila eksplan mampu menggandakan tunas lebih banyak maka akan diikuti dengan tinggi tunas yang semakin rendah. [13] melaporkan bahwa meningkatnya konsentrasi BAP akan meningkatkan jumlah tunas dan menurunkan rata-rata panjang tunas. Pendapat tersebut didukung dengan hasil penelitian [9] semakin banyak tunas yang terbentuk akan mempengaruhi panjang tunas yang lebih pendek karena energi yang dibutuhkan untuk tinggi pucuk lebih banyak digunakan untuk penggandaan tunas.

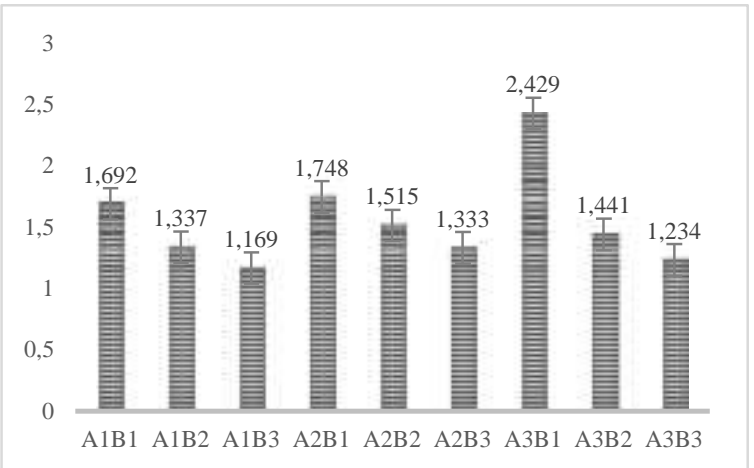

GAMBAR 1. RERATA TINGGI TUNAS PADA EKSPLAN VANILI DENGAN PENAMBAHAN KINETIN DAN BAP

Penambahan berbagai konsentrasi Kinetin dan BAP ditujukan untuk memperoleh konsentrasi yang optimal untuk penggandaan dan pertumbuhan tunas vanili yang berasal dari eksplan ruas vanili. Gambar 2 (a,b,c,d) memperlihatkan proses pembentukan pucuk tunas dan kemampuan membentuk tunas ganda pada kultur vanili.

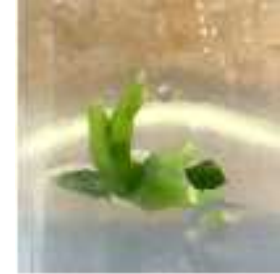

(a)

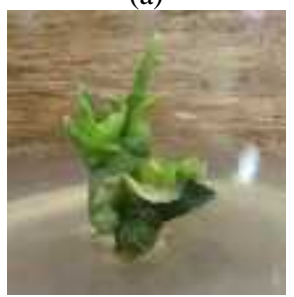

(c)

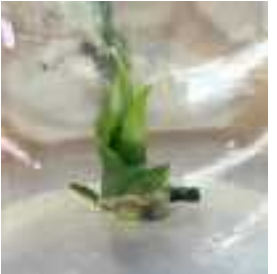

(b)

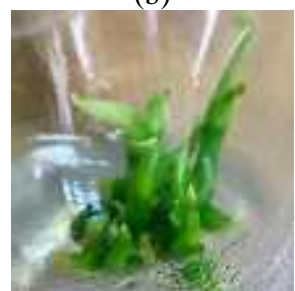

(d)
GAMBAR 2. PENGGANDAAN TUNAS PADA EKSPLAN VANILI DENGAN PENAMBAHAN KINETIN DAN BAP

\section{Berat Basah Tunas (gram)}

Berat basah tunas juga merupakan salah satu indikator keberhasilan zat pengatur tumbuh dari golongan sitokinin seperti Kinetin dan BAP mempengaruhi pembentukan tunas kultur vanili.

Berdasar Tabel 3 dapat diketahui bahwa penambahan Kinetin 0 mg.L-1 + BAP 1.5 mg.L-1 kedalam media dasar MS efektif dalam meningkatkan berat basah tunas dengan rerata 0,93 gram/eksplan.

TABEL 3. RERATA BERAT BASAH TUNAS PADA EKSPLAN VANILI DENGAN PENAMBAHAN KINETIN DAN BAP

\begin{tabular}{cccc}
\multicolumn{2}{c}{ Konsentrasi (mg.L-1) } & Rerata Berat & BasahTunas \\
Kinetin & BAP & & \\
\hline 0.0 & 0.5 & 0.46 & $\mathrm{a}$ \\
0.0 & 1.5 & 0.93 & $\mathrm{c}$ \\
0.0 & 2.5 & 0.72 & $\mathrm{abc}$ \\
1.0 & 0.5 & 0.75 & $\mathrm{bc}$ \\
1.0 & 1.5 & 0.59 & $\mathrm{ab}$ \\
1.0 & 2.5 & 0.58 & $\mathrm{ab}$ \\
2.0 & 0.5 & 0.70 & $\mathrm{abc}$ \\
2.0 & 1.5 & 0.62 & $\mathrm{ab}$ \\
2.0 & 2.5 & 0.54 & $\mathrm{ab}$
\end{tabular}

Keterangan: Angka-angka yang diikuti oleh huruf yang sama dinyatakan berbeda tidak nyata berdasar uji BNT 0,05.

Penambahan konsentrasi BAP sebesar $1.5 \mathrm{mg}$.L1 mendukung pertumbuhan dan berat basah tunas vanili. Sesuai dengan pendapat [14] yang menyatakan bahwa zat pengatur tumbuh Benzyl Adenin paling banyak digunakan untuk memacu penggandaan tunas karena mempunyai aktivitas yang lebih kuat dibandingkan dengan jenis sitokinin yang lain. 


\section{KESIMPULAN DAN SARAN}

Hasil penelitian menunjukkan bahwa perbanyakan tunas vanili yang tercepat terjadi pada eksplan yang diinokulasikan dalam media MS + Kinetin 2 mg.L-1 dengan rerata 8,7 hari setelah inokulasi. Rerata jumlah tunas 7,56 pucuk/eksplan dengan bobot basah rata-rata tertinggi 0,93 gram/eksplan pada penambahan BAP 1,5 mg. L-1 pada pengukuran 70 hari setelah inokulasi.

Saran yang dapat disampaikan adalah ketersediaan eksplan steril sebagai bahan tanam harus tetap terjaga secara kuantitatif dan kualitatif.

\section{UCAPAN TERIMA KASIH}

Penelitian dilaksanakan dengan pendanaan dan kontrak penelitian PNBP Politeknik Negeri Jember Tahun Anggaran 2020.

\section{Daftar Pustaka}

[1] Santi, F S. Ingin Mengembangkan Vanili? Gunakan Benih Unggul Dari Kebun Sumber Benih Vanili (Vanilla planifolia) Di Indonesia. Direktorat Perbenihan, Direktorat Jenderal Perkebunan Kementrian Pertanian. 2021. http://ditjenbun.pertanian.go.id/

[2] B C Tan, C F Chin and P Alderson. Optimisation of plantlet regeneration from leaf and nodal derived callus of Vanilla planifolia Andrews. Plant Cell Tiss Organ Cult (2011) 105:457-463. DOI 10.1007/s11240-010-9866-6

[3] A M Njoroge, Gitonga L, Mumuta E, L Mimano, Macharia C, Wasilwa L, Muli S, Kiuru P and Mungai A. Propagation of High Quality Planting Materials of Vanilla (Vanilla planifolia) Through Tissue Culture. 2015.

https://www.researchgate.net/publication/26594801 $\underline{7}$

[4] A G Pinaria. Liew, ECY and Burgess, LW. Fusarium species associated with vanilla stem rot in Indonesia, Australasian Plant Pathology (2010) 39:176-183.

[5] S Gantait and S. Kundu. In vitro biotechnological approaches on Vanilla planifolia Andrews: advancements and opportunities. Acta Physiol Plant (2017) 39:196. DOI 10.1007/s11738-017-2462-1
[6] V M Salazar-Rojas, Herrera-Cabrera, BE. DelgadoAlvarado, A. Soto-Hernández, M. CastilloGonza'lez, F and Cobos-Peralta, M. Chemotypical variation in Vanilla planifolia Jack. (Orchidaceae) from the Puebla-Veracruz Totonacapan region. Genet Resour Crop Evol. 2011. DOI 10.1007/s10722-0119729-y

[7] A Ramos-Castellá. Iglesias-Andreu, LA. Bello-Bello, $\mathrm{J}$ and Lee-Espinosa, H. Improved propagation of vanilla (Vanilla planifolia Jacks. Ex Andrews) using a temporary immersion system. In Vitro Cell.Dev.Biol._Plant (2014) 50:576-581. DOI 10.1007/s11627-014-9602-8.

[8] G Renuga and S. K. S. N, "Induction of vanillin related compounds from nodal explants of Vanilla planifolia using BAP and Kinetin," Asian Journal of Plant Science and Research, 2014, 4(1):53-61.

[9] D N Erawati, I Wardati, S Humaida and U Fisdiana. Micropropagation of Vanilla (Vanilla planifolia Andrews) with Modification of Cytokinins. IOP Conf. Series: Earth and Environmental Science 411 (2020) 012009. IOP Publishing. doi:10.1088/1755$1315 / 411 / 1 / 012009$

[10] N Jadid, T Nurhidayati and Priyono. In Vitro Clonal Propagation of Vanilla planifolia Andrews Using Microshoot-derived Node Explants. J. Appl. Environ. Biol. Sci., 5(6)105-110, 2015.

[11] K Karyanti. Pengaruh Beberapa Jenis Sitokinin Pada Multiplikasi Tunas Anggrek Vanda douglas Secara In Vitro. Jurnal Bioteknologi \& Biosains Indonesia 4(1):36-43. 2017

[12] D N Erawati, U Fisdiana dan M Kadafi. The response of Vanilla Explant (Vanilla planifolia) to BAP and NAA Stimulation through Micropropagation Technique. Agriprima Journal of Applied Agricultural Sciences, 4(2):146-153.2020. https://doi.org/10.25047/agriprima.v4i2.362.

[13] I Mushimiyimana, T Asiimwe, C Dusabe, F Gatunzi, J Ndahimana, V Ahishakiye, J Kahia and D Gahakwa. In Vitro Propagation of Vanilla in Rwanda. Rwanda Journal, Volume 24 Series E 2011: Agricultural Sciences. 67-74.

[14] E G Lestari. Peranan Zat Pengatur Tumbuh dalam Perbanyakan Tanaman melalui Kultur Jaringan. Jurnal AgroBiogen 7(1):63-68. 2011 